\title{
УДК 389.14:621.317:006.354
}

Т. Б. Гордієнко, к.т.н.

Одеська державна академія технічного регулювання та якості, м. Одеса

\section{ОЦНЮВАННЯ ДІЯЛЬНОСТІ ТЕХНІЧНИХ КОМІТЕТІВ СТАНДАРТИЗАЦІЇ ІЗ ЗАСТОСУВАННЯМ УЗАГАЛЬНЕНОГО КРИТЕРІЮ}

Розглянуто особливості оцінювання діяльності технічних комітетів стандартизації України. Запропоновано використання узагальненого критерію оиінювання діяльності начіонального ТК, який враховує не лише кількість розроблених технічним комітетом начіональних стандартів, а й інших нормативних документів. Представлені результати порівняльного аналізу оцінювання діяльності національних технічних комітетів різних галузей економіки.

Ключові слова: технічний комітет стандартизаиії, оиінювання, критерій, міжнародна організація стандартизаиії, регіональна організаиія стандартизаџії.

\section{Вступ}

Ефективність діяльності національних технічних комітетів стандартизації (ТК) на національному, міжнародному та регіональному рівнях залишається одним із актуальних питань щодо забезпечення потреб урядових та неурядових структур. Проведення досліджень 3 метою оцінки ефективності діяльності національних ТК та виконання ними функцій, передбачених Типовим положенням про ТК [1], зокрема 3 урахуванням лише кількості розроблених національних стандартів (ДСТУ), гармонізованих $з$ міжнародними і регіональними (далі - гармонізовані ДСТУ) [2], а також деяких інших показників [3,4] не давали об’єктивного результату.

Оцінювання роботи національних ТК доцільно здійснювати не лише за показником кількості розроблених ДСТУ, гармонізованих ДСТУ за відповідними групами (сферами діяльності), а й 3 урахуванням факторів, що найбільше впливають на ефективність роботи ТК. При цьому варто враховувати, що не всі ТК мають міжнародні аналоги в міжнародних організаціях стандартизації (МОС) або регіональних організаціях стандартизації (РОС), можливість співпрацювати 3 ними і розробляти гармонізовані ДСТУ. Саме через специфіку сфери діяльності певні ТК розробляють лише ДСТУ, галузеві стандарти, стандарти організацій (СОУ) і технічні умови (ТУ).

Пріоритети для національної стандартизації щодо розроблення гармонізованих ДСТУ визначені чинним законодавством України та іншими нормативними документами (НД). Враховуючи підготовку України до укладання з Європейським Союзом (СС) Угоди про оцінку відповідності та прийнятності промислової продукції (АСАА), впровадження європейський стандартів, застосування яких сприймається як доказ відповідності вимогам директив “нового підходу”, $є$ першочерговим пріоритетом.

Актуальним питанням є розроблення спеціального критерію оцінювання діяльності ТК, який би враховував різні фактори його діяльностi.

\section{1. Узагальнений критерій оцінки діяль-} ності ТК

Для визначення ефективності діяльності ТК щодо впровадження міжнародних стандартів, розроблення національних стандартів і стандартів інших рівнів у працях [5-8] запропоновано використовувати певний узагальнений критерій оцінки цієї діяльності $\delta_{\Sigma}$

$$
\delta_{\Sigma}=a \cdot \frac{K_{D S T U h}}{K_{\Sigma}}+b \cdot \frac{K_{D S T U}}{K_{\Sigma}}+c \cdot \frac{K_{S O U}}{K_{\Sigma}},
$$

де

$K_{D S T U h}-$ загальна кількість розроблених національним ТК гармонізованих ДСТУ;

$K_{D S T U}$ - загальна кількість розроблених національним ТК ДСТУ;

$K_{\text {SOU }}$ - загальна кількість розроблених національним ТК СОУ, ТУ;

$K_{\Sigma}$ - загальна кількість розроблених національним ТК НД;

$a$ - коефіцієнт вагомості гармонізованого ДСТУ для національної стандартизації;

$b$ - коефіцієнт вагомості ДСТУ для національної стандартизації;

c - коефіцієнт вагомості СОУ, ТУ для національної стандартизації.

3 урахуванням пріоритетів для національної стандартизації, встановлено три умовні рівні значення критерію ефективності діяльності ТК 
$\delta_{\Sigma}$ (від 0 до 1$)$ щодо розроблення гармонізованих ДСТУ, ДСТУ та інших стандартів, які визначатимуть три рівні ефективності діяльності ТК для будь якої галузі або сектора економіки: “високий”, “середній”, “низький” (таблиця 1). Оскільки розроблення гармонізованих ДСТУ є пріоритетним для національної стандартизації, коефіцієнт вагомості їхнього впровадження приймається за 1 чи близьким до 1. Коефіцієнти вагомості для ДСТУ, СОУ та ТУ встановлюються залежно від сектору або галузі діяльності.

\section{Таблиця 1}

\begin{tabular}{|c|c|c|}
\hline $\begin{array}{c}\text { Рівень } \\
\text { оцінки } \\
\text { діяльності } \\
\text { ТК }\end{array}$ & $\begin{array}{c}\text { Особливості рівня } \\
\text { оцінки діяльності } \\
\text { ТК }\end{array}$ & $\begin{array}{c}\text { Значення уза- } \\
\text { гальненого кри- } \\
\text { терію оцінки } \\
\text { діяльності ТК, } \\
\delta_{\Sigma}\end{array}$ \\
\hline $\begin{array}{c}\text { “Високий” } \\
\text { (В) }\end{array}$ & $\begin{array}{l}\text { Велика кількість } \\
\text { гармонізованих } \\
\text { стандартів за сфе- } \\
\text { рою діяльності ТК }\end{array}$ & $\delta_{\Sigma} \geq 0,70$ \\
\hline $\begin{array}{l}\text { "Середній" } \\
\text { (C) }\end{array}$ & $\begin{array}{l}\text { Середня кількість } \\
\text { гармонізованих } \\
\text { стандартів за сфе- } \\
\text { рою діяльності ТК }\end{array}$ & $0,70>\delta_{\Sigma}>0,30$ \\
\hline $\begin{array}{c}\text { "Низький" } \\
(\mathrm{H})\end{array}$ & $\begin{array}{l}\text { Мала кількість або } \\
\text { відсутність гармо- } \\
\text { нізованих міжна- } \\
\text { родних стандартів } \\
\text { за сферою діяль- } \\
\text { ності ТК }\end{array}$ & $\delta_{\Sigma} \leq 0,30$ \\
\hline
\end{tabular}

Використовуючи формулу (1) і дані звітності ТК щодо кількості розроблених стандартів за певний період, можна розрахувати значення узагальненого критерію оцінки $\delta_{\Sigma}$ для будь-якого ТК. При цьому для отримання об'єктивної оцінки діяльності ТК варто враховувати всі фактори, які можуть безпосередньо впливати на ефективність роботи ТК.

2. Порівняльний аналіз результатів оцінювання діяльності національних ТК різних галузей

Здійснене оцінювання діяльності ТК таких галузей як: метрологія та приладобудування; паливно-енергетичний комплекс; металургійна та гірничодобувна промисловість; агропромисловий комплекс (табл. 2). Отримані значення узагальненого критерію діяльності ТК $\delta_{\Sigma}$ для зазначених галузей.

Порівняльний аналіз отриманих оцінок показав для загалом 40 ТК цих галузей, що найбі- льшу кількість “високого" рівня оцінки діяльності отримали ТК у сфері метрології та приладобудування і металургійної та гірничодобувної промисловості - по 6 (37,5 \%), “середнього” рівня оцінки - ТК агропромислового комплексу - 9 $(60,0$ \%), “низького” рівня оцінки - ТК паливноенергетичного комплексу, металургійної та гірничодобувної промисловості, агропромислового комплексу - по 3 (33,3 \%).

Таблиця 2

\begin{tabular}{|l|c|c|c|c|}
\hline \multirow{2}{*}{$\begin{array}{l}\text { Сфера діяльно- } \\
\text { сті ТК }\end{array}$} & $\begin{array}{c}\text { Загальна } \\
\text { кількість } \\
\text { ТК }\end{array}$ & \multicolumn{3}{|c|}{$\begin{array}{c}\text { Кількість ТК з рів- } \\
\text { нем оцінки загальної кіль- } \\
\text { кості оцінки) }\end{array}$} \\
\cline { 3 - 5 } & В & С & Н \\
\hline $\begin{array}{l}\text { Метрологія та } \\
\text { приладобуду- } \\
\text { вання (1) }\end{array}$ & 7 & $\begin{array}{c}6 \\
(37,5)\end{array}$ & $\begin{array}{c}1 \\
(6,5)\end{array}$ & $\begin{array}{c}0 \\
(0,0)\end{array}$ \\
\hline $\begin{array}{l}\text { Паливно- } \\
\text { енергетичний } \\
\text { комплекс (2) }\end{array}$ & 8 & $\begin{array}{c}2 \\
(12,5)\end{array}$ & $\begin{array}{c}3 \\
(20,0)\end{array}$ & $\begin{array}{c}3 \\
(33,3)\end{array}$ \\
\hline $\begin{array}{l}\text { Металургійна } \\
\text { та гірничо- } \\
\text { добувна проми- } \\
\text { словість (3) }\end{array}$ & 11 & $\begin{array}{c}6 \\
(37,5)\end{array}$ & $\begin{array}{c}2 \\
(13,5)\end{array}$ & $\begin{array}{c}33 \\
(33,3)\end{array}$ \\
\hline $\begin{array}{l}\text { Агропромис- } \\
\text { ловий комплекс } \\
\text { (4) }\end{array}$ & 14 & $\begin{array}{c}2 \\
(12,5)\end{array}$ & $\begin{array}{c}9 \\
(60,0)\end{array}$ & $\begin{array}{c}3 \\
(33,4)\end{array}$ \\
\hline \multicolumn{1}{|c|}{ Загалом: } & 40 & $\begin{array}{c}16 \\
(100)\end{array}$ & $\begin{array}{c}15 \\
(100)\end{array}$ & $\begin{array}{c}9 \\
(100)\end{array}$ \\
\hline
\end{tabular}

На рис. 1 наведене графічне відображення результатів оцінювання за сферами діяльності ТК у відповідності до табл. 2.

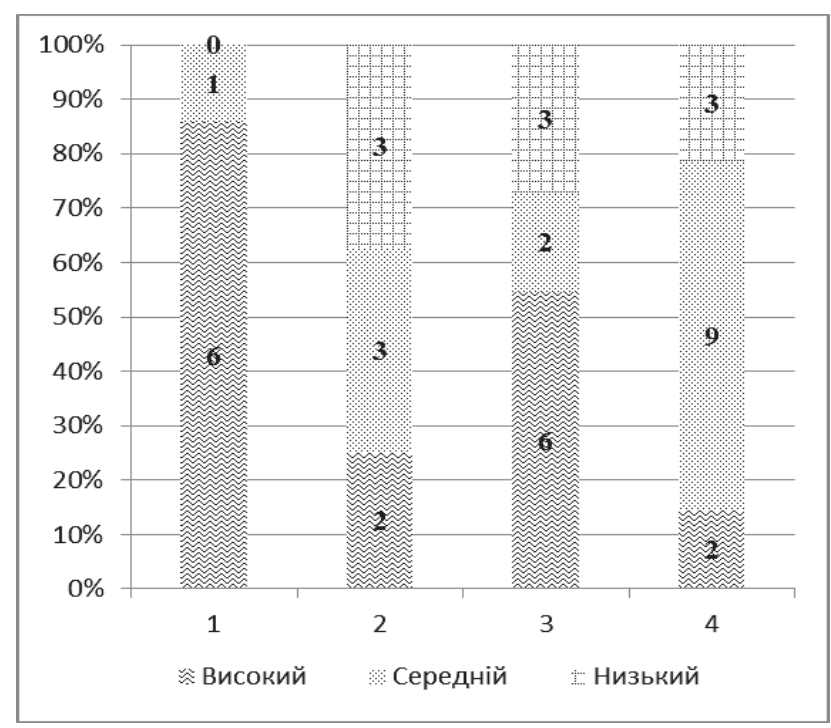

Рисунок 1 - Графічне відображення результатів оцінювання за сферами діяльності ТК 
3 наведеного рисунку видно, що за сферою (1) високий рівень мають більше $80 \%$ ТК від їх загальної кількості, а за сферою (4) таких ТК лише трохи більше $10 \%$. В той же час за сферою (4) встановлена найбільша кількість ТК 3 середнім рівнем - більше $60 \%$ ТК від їх загальної кількості [8-15].

3. Порівняльний аналіз участі ТК різних галузей у роботі міжнародних і регіональних організацій стандартизації

В рамках проведеного оцінювання діяльності ТК також встановлена участь конкретних ТК різних сфер діяльності, які досліджувалися, у роботі структурних органів МОС і РОС.

Результати порівняльного аналізу наведені у табл. 3 і на рис. 2.

Таблиця 3

\begin{tabular}{|l|c|c|c|c|}
\hline \multirow{2}{*}{$\begin{array}{l}\text { Сфера діяльно- } \\
\text { сті ТК }\end{array}$} & $\begin{array}{c}\text { Кагальна } \\
\text { кількість } \\
\text { ТК }\end{array}$ & \multicolumn{3}{|c|}{ Кількість ТК (\%) } \\
\cline { 3 - 5 } $\begin{array}{l}\text { Метрологія та } \\
\text { приладобуду- } \\
\text { вання (1) }\end{array}$ & 8 & $\begin{array}{c}21 \\
(33,0)\end{array}$ & $\begin{array}{c}2 \\
(5,0)\end{array}$ & $\begin{array}{c}23 \\
(21,0)\end{array}$ \\
\hline $\begin{array}{l}\text { Паливно- } \\
\text { енергетичний } \\
\text { комплекс (2) }\end{array}$ & 8 & $\begin{array}{c}7 \\
(11,0)\end{array}$ & $\begin{array}{c}4 \\
(9,0)\end{array}$ & $\begin{array}{c}11 \\
(10,0)\end{array}$ \\
\hline $\begin{array}{l}\text { Металургійна } \\
\text { та гірничо- } \\
\text { добувна проми- } \\
\text { словість (3) }\end{array}$ & 16 & $\begin{array}{c}21 \\
(33,0)\end{array}$ & $\begin{array}{c}23 \\
(52,0)\end{array}$ & $\begin{array}{c}44 \\
(41,0)\end{array}$ \\
\hline $\begin{array}{l}\text { Агропромисло- } \\
\text { вий комплекс } \\
\text { (4) }\end{array}$ & 29 & $\begin{array}{c}15 \\
(23,0)\end{array}$ & $\begin{array}{c}15 \\
(34,0)\end{array}$ & $\begin{array}{c}30 \\
(28,0)\end{array}$ \\
\hline \multicolumn{1}{|c|}{ Загалом: } & 61 & $\begin{array}{c}64 \\
(100)\end{array}$ & $\begin{array}{c}44 \\
(100)\end{array}$ & $\begin{array}{c}108 \\
(100)\end{array}$ \\
\hline
\end{tabular}

Зазначені дані щодо участі національних ТК в MOC і РОС свідчать, що найкраще національні ТК представлені в ТК МОС у сфері метрології та приладобудування і металургійної та гірничодобувної промисловості (по 33 \%), а в ТК РОС ТК металургійної та гірничодобувної промисловості (52\%). Найгірше представлені в ТК МОС і POC національні ТК паливно-енергетичного комплексу (11 \% і 9 \% відповідно).

4. Порівняльний аналіз участі ТК різних галузей у роботі міжнародних $\mathrm{i}$ регіональних організацій стандартизації

В рамках зазначеного оцінювання діяльності ТК також встановлено дублювання сфер діяльності конкретних ТК різних сфер, які досліджувалися.

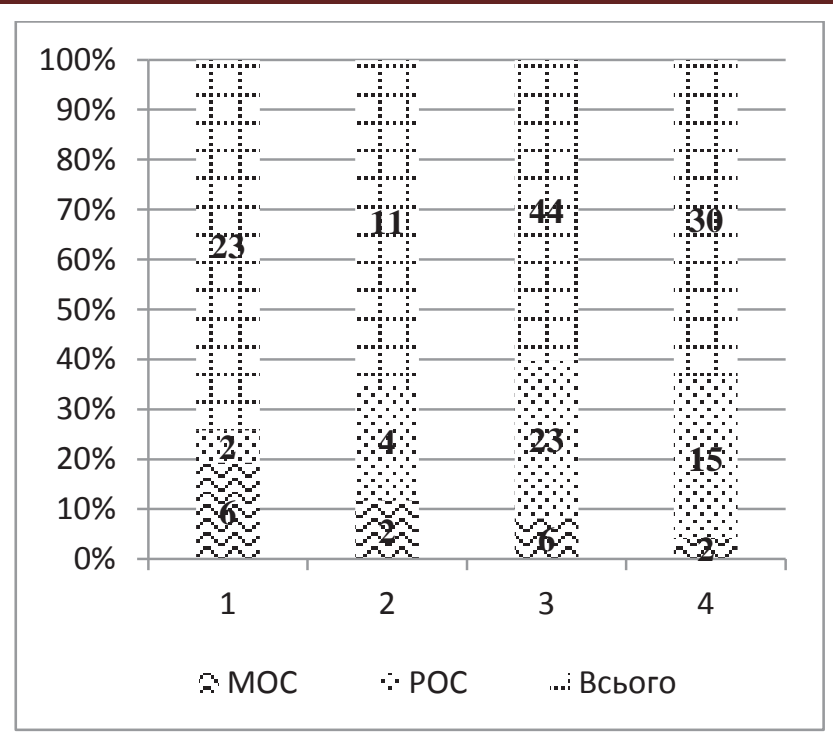

Рисунок 2 - Графічне відображення участі ТК за сферами діяльності в МОС і РОС

Результати порівняльного аналізу наведені у табл. 4 і на рис. 3 [8-15].

Таблиця 4

\begin{tabular}{|l|c|c|c|}
\hline $\begin{array}{l}\text { Сфера діяльно-- } \\
\text { сті ТК }\end{array}$ & $\begin{array}{c}\text { Загальна } \\
\text { кількість } \\
\text { ТК }\end{array}$ & $\begin{array}{c}\text { Кількість } \\
\text { ТК 3 } \\
\text { дублю- } \\
\text { ванням } \\
\text { сфер (\% } \\
\text { ТК) }\end{array}$ & $\begin{array}{c}\text { Кількість } \\
\text { кодів за } \\
\text { ДК 004 з } \\
\text { дублю- } \\
\text { ванням (\% } \\
\text { кодів) }\end{array}$ \\
\hline $\begin{array}{l}\text { Метрологія та } \\
\text { приладобуду- } \\
\text { вання (1) }\end{array}$ & 8 & $5(62,5)$ & $7(19,0)$ \\
\hline $\begin{array}{l}\text { Паливно- } \\
\text { енергетичний } \\
\text { комплекс (2) }\end{array}$ & 8 & $6(75,0)$ & $14(38,0)$ \\
\hline $\begin{array}{l}\text { Металургійна } \\
\text { та гірничо- } \\
\text { добувна проми- } \\
\text { словість (3) }\end{array}$ & 16 & $3(18,8)$ & $7(19,0)$ \\
\hline $\begin{array}{l}\text { Агропромис- } \\
\text { ловий комплекс } \\
\text { (4) }\end{array}$ & 29 & $5(17,2)$ & $9(24,0)$ \\
\hline \multicolumn{1}{|c|}{ Загалом: } & 61 & $19(31,1)$ & $37(100)$ \\
\hline
\end{tabular}

Зазначені дані щодо дублювання сфер діяльності національних ТК свідчать, що найбільшу кількість дублювання мають ТК паливноенергетичного комплексу $(75,0 \%)$ і у сфері метрології та приладобудування $(62,5 \%)$, а найменшу - ТК агропромислового комплексу (17,2 \%) і металургійної та гірничодобувної промисловості (18,8 \%). Загалом 361 дослідженого ТК дублювання сфер діяльності мають 19 ТК (31,1%). 
Найбільшу кількість дублювання за кодами ДК 004 [16] мають ТК паливно-енергетичного комплексу - 14 з 37 (38\%).

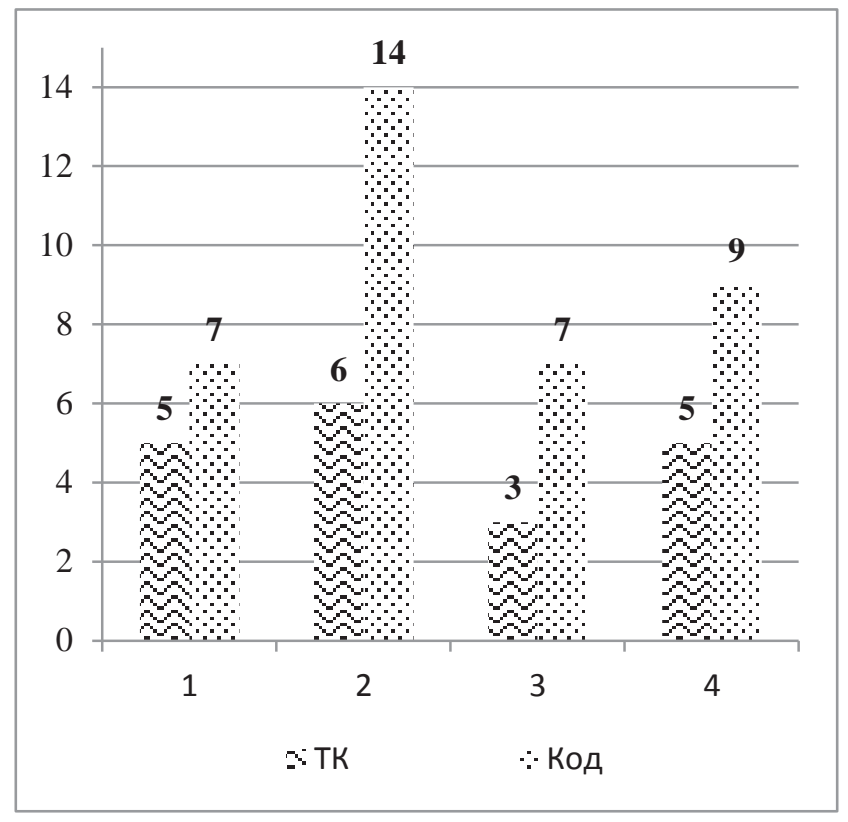

Рисунок 3 - Графічне відображення дублювання за сферами діяльності ТК різних галузей

\section{Висновки}

Визначено, що результати діяльності ТК характеризує низка об'єктивних і суб'єктивних показників, традиційні з яких базуються на даних щодо кількості розроблених стандартів (у т. ч. гармонізованих), рівня участі у роботі МOC i POC, наявності дублювання сфери діяльності 3 іншими ТК, фінансових і технічних можливостей тощо, однак не враховуються інші вагомі фактори. Тому оцінювання діяльності ТК необхідно здійснювати 3 урахуванням усіх впливних факторів.

Виявлено, що національні ТК, у яких є міжнародні аналоги в МОС або РОС, мають можливість співпрацювати з ними, розробляти гармонізовані ДСТУ, більш затребувані вітчизняними галузями економіки та мають вищий рівень оцінки діяльності. Національні ТК, які через специфіку своєї сфери діяльності не мають “дзеркальних" ТК в МОС і РОС, розробляють лише ДСТУ, СОУ і ТУ, мають менш низький рівень оцінки їх діяльності та працюють ефективно лише до того часу, поки розроблені ними НД відносяться до пріоритетних на рівні держави або затребувані на рівні вітчизняних організацій та підприємстввиробників.

За результатами проведених досліджень можна стверджувати, що запропонований підхід щодо застосування узагальненого критерію оцін- ки діяльності ТК дає змогу більш об'єктивно оцінити ефективність діяльності ТК незалежно від тривалості його роботи та абсолютного значення кількості розроблених НД.

\section{Список використаних джерел}

1. Типове положення про технічний комітет стандартизації / Затв. наказом Держстандарту України від 20.05.2002 № 298, зареєстр. У Мін'юсті України 11.07.2002 за № 578/6866.

2. Гордієнко Т. Б. Деякі аспекти оцінки ефективності діяльності національних технічних комітетів стандартизації у 2008-2009 pp. / Т. Б. Гордієнко // Стандартизація, сертифікація, якість. - 2010. - № 2. - С. 4-9.

3. Гордієнко Т. Б. Оцінювання діяльності українських технічних комітетів стандартизації 3 застосуванням методу аналізу ієрархій / Т. Б. Гордієнко // Тези доп. 10-ї Ювіл. Міжнар. наук.-практ. конф. "Якість, стандартизація, контроль: теорія і практика”. - Ялта, 2010. - С. 3638.

4. Гордієнко Т. Б. Методика оцінки ефективності діяльності технічних комітетів стандартизації із застосуванням метода аналізу ієрархій / Т. Б. Гордієнко, О. М. Величко // Праці Першої наук.-практ. конф. "Інформаційно-вимірювальні технології, технічне регулювання та менеджмент якості” / ОДІВТ. - Одеса, 2010. - С. 28-35.

5. Гордієнко Т. Б. Узагальнений критерій оцінювання ефективності діяльності національних технічних комітетів стандартизації / T. Б. Гордієнко // I Міжнар. наук. конф. пам'яті професора Володимира Поджаренка "Вимірювання, контроль та діагностика в технічних системах" (ВКДТС-2011), 21-24 вересня 2001. - Вінниця, 2011.

6. Гордієнко Т. Б. Складові узагальненого критерію для оцінювання ефективності діяльності національних технічних комітетів стандартизації / Т. Б. Гордієнко // Якість, стандартизація, контроль: теорія i практика: тези доп. 11-ї Міжнар. наук.-практ. конф. - Ялта: АТМ України, 2011. - С. 23-26.

7. Гордієнко Т. Б. Узагальнений критерій оцінювання ефективності діяльності національних технічних комітетів стандартизації / T. Б. Гордієнко // I Міжнар. наук. конф. "Вимірювання, контроль та діагностика в технічних системах": тези доп. - Вінниця, 2011. C. 143.

8. Гордієнко Т. Б. Оцінювання ефективності діяльності технічних комітетів стандартизації в галузі приладобудування із застосуванням узагальненого критерію / Т. Б. Гордієнко // Якість, 
стандартизація, контроль: теорія і практика: тези доп. 13-ї Міжнар. наук.-практ. конф. "Якість, стандартизація, контроль: теорія і практика”. Ялта-Київ: АТМ України, 2013. - С. 35-37.

9. Гордиенко Т. Б. Особенности деятельности технических комитетов международных и региональных организаций в области метрологии / Т. Б. Гордиенко // “Метрология 2009": тезисы докладов Междунар. научно-практ. конф. Минск: БелГИМ, 2009. - С. 98-102.

10. Gordiyenko T. B. Activity the technical committees standardization of international organizations in field of metrology / T. B. Gordiyenko, L. V. Kolomiets, O. M. Velychko // Зб. наук. праць Одеської держ. академії технічного регулювання та якості. - Одеса, 2012. - Вип. 1 (1). - С. 11-16.

11. Гордієнко Т. Деякі аспекти оцінювання діяльності національних технічних комітетів стандартизації у сфері метрології / Т. Гордієнко, О. Величко // Метрологія та прилади. - 2011. № 2. - C. 5-11.

12. Гордієнко Т. Б. Аналіз діяльності українських ТК паливно-енергетичного комплексу / Гордієнко Т. Б. // Стандартизація, сертифікація, якість. - 2010. - № 5. - С. 27-31.

13. Гордієнко Т. Б. Оцінювання ефективності діяльності технічних комітетів стандарти- зації паливно-енергетичного комплексу із застосуванням узагальненого критерію / Гордієнко Т. Б. // Якість, стандартизація, контроль: теорія і практика: тези доп. 12-ї Міжнар. наук.-практ. конф. - Ялта: АТМ України, 2012. - С. 47-49.

14. Гордієнко Т. Б. Діяльність українських технічних комітетів стандартизації металургійної та гірничодобувної промисловості / Т.Б. Гордієнко // Металлургическая и горнорудная промышленность. - 2014. - № 4. - С. 105-111.

15. Гордієнко Т. Б. Аналіз діяльності українських технічних комітетів стандартизації агропромислового комплексу / Т.Б. Гордієнко // Стандартизація, сертифікація, якість. - 2013. № 3. - С 17-23.

16. Український класифікатор нормативних документів (ICS:2005, MOD): ДК 004:2008. [Чинний від 2009-04-01]. - К.: Держспоживстандарт України, 2009. - 104 с. (Національний класифікатор України).

\section{Надійила до редакиї 25.05.2015}

Рецензент: д.т.н., професор Коломієць Л. В., Одеська державна академія технічного регулювання та якості, м. Одеса.

\section{Т. Б. Гордиенко, к.т.н.}

\section{ОЦЕНИВАНИЕ ДЕЯТЕЛЬНОСТИ ТЕХНИЧЕСКИХ КОМИТЕТОВ СТАНДАРТИЗАЦИИ С ПРИМЕНЕНИЕМ ОБОБЩЕННОГО КРИТЕРИЯ}

Рассмотрены особенности оценивания деятельности технических комитетов стандартизации Украины. Предложено использование обобщченного критерия оиенивания деятельности национального технического комитета, который учитывает не только количество разработанных техническим комитетом национальных стандартов, но и других нормативных документов. Представлены результаты сравнительного анализа оценки деятельности национальньх технических комитетов различных отраслей экономики.

Ключевые слова: технический комитет стандартизации, оченивание, критерий, международная организация стандартизацчи, региональная организация стандартизации.

\section{T. B. Gordiyenko, $\mathrm{PhD}$}

\section{EVALUATION OF TECHNICAL COMMITTEE FOR STANDARDIZATION WITH USING GENERALIZED CRITERIA}

Features are considered in relation to the evaluation of technical committees for standardization activity of Ukraine. The use of generalized criteria for evaluation of the national technical committee, which takes into account not only the number of national standards developed by technical committee, but other normative documents are proposal. Results comparative analysis evaluation of activities national technical committees from different industry economy is presented.

Keywords: technical committee for standardization, evaluation, criteria, international organization for standardization, regional organization for standardization. 